\title{
TITIK TEMU ANTARA ISLAM DAN FILSAFAT
}

\author{
A. R. Taufiq Satria Azhar \\ IAIN Syekh Nurjati
}

\begin{abstract}
Abstrak: Manusia adalah mahkluk berfikir yang tidak pernah lelah untuk mencari hakikat dari segala sesuatu yang ada di dunia ini. Setidaknya terdapat tiga cara yang dapat ditempuh manusia dalam menemukan kebenaran tersebut, yaitu melalui agama, filsafat dan ilmu pengetahuan. Tulisan ini akan berupaya mengungkap karakteristik dari masing-masing cara tersebut dan titik temu dari tiga cara dalam menggapai kebenaran tersebut. Dengan demikian manusia akan semakin menyadari tentang bagaimana terbentuknya kebenaran yang saat ini sedang ia yakini.
\end{abstract}

Kata kunci: Agama, Filsafat, Ilmu Pengetahuan

\section{A. Pendahuluan}

Manusia adalah makhluk berfikir, berfikir adalah bertanya, bertanya adalah mencari jawaban, dan mencari jawaban adalah mencari kebenaran, mencari jawaban tentang sesuatu berarti mencari kebenaran tentang sesuatu itu. Mencari jawaban tentang hidup misalnya, adalah mencari kebenaran tentang hidup. Dengan demikian pada akhirnya manusia adalah makhluk pencari kebenaran.

Cara manusia mencari dan menemukan kebenaran itu ada tiga macam, yaitu dengan agama, filsafat dan dengan ilmu pengetahuan. Antara satu dengan lainnya mempunyai titik persamaan. Titik persamaan antara keduanya adalah bahwa baik agama, maupun filsafat setidak-tidaknya bertujuan atau berurusan dengan hal yang sama, yaitu kebenaran. ${ }^{2}$ Meskipun demikian hlm., 284

${ }^{1}$ Tadjab, dkk. Dimensi-Dimensi Studi Islam. Surabaya : Karya Aditama. 1994.,

2 Tadjab, dkk. Dimensi-Dimensi Studi Islam. Ibid., 284. Lihat juga Endang Saefuddin Anshari, Wawasan Islam. Jakarta : Rajawali Press. 1982., hlm., 222. 
terdapat pula perbedaan duantara keduanya dalam memperoleh hasil kebenaran. ${ }^{3}$

Perbedaan antara Filsafat dan Agama terletak pada dasar dan metode menghampiri/menemukan kebenaran tersebut: Filsafat menghampiri kebenaran dengan mengembarakan (mengelanakan atau menualangkan) akalbudi dengan secara radikal dan secara integral, dengan tidak mau terikat oleh apa pun juga, kecuali oleh "tangannya" sendiri, yaitu logika; Sedangkan Agama menghampiri kebenaran dengan berorientasi kepada Kitab Suci, Wahyu llahi, Firman Tuhan untuk manusia dalam planet bumi ini. ${ }^{4}$

\section{B. Islam \\ 1. Pengertian Islam}

Kata Islam berasal dari bahasa Arab: (al-islam):memiliki arti "berserah diri kepada Tuhan"). Islam adalah agama yang mengimani satu Tuhan, yaitu Allah SWT. Islam memiliki arti "penyerahan? atau penyerahan diri sepenuhnya kepada Tuhan Islam mengajarkan bahwa Allah SWT. Menurun-kan firman-Nya kepada manusia melalui para nabi dan rasul utusan-Nya, dan meyakini dengan sungguh-sungguh bahwa Muhammad adalah nabi dan rasul terakhir yang diutus ke dunia oleh Allah SWT. ${ }^{5}$

Pengertian Islam menurut Rosihon, dkk, dapat dibedah dari dua aspek, yaitu aspek kebahasaan dan aspek peristilahan. Dari segi kebahasaan, Islam berasal dari bahasa Arab, yaitu dari kata salima yang mengandung arti selamat 'sentosa, dan damai. Dari kata salima selanjutnya diubah menjadi bentuk aslama yang berarti berserah diri masuk dalam kedamaian. Oleh sebab itu, orang yang berserah diri, patuh, dan taat kepada Allah SWT. disebut sebagai orang Muslim. Dari uraian tersebut, dapat ditarik kesimpulan bahwa kata Islam dari segi kebahasaan mengandung arti patuh,

${ }^{3}$ Kebenaran filsafat adalah jebenaran nisbi karena sekedar berdasarkan ra'yu (ratio, reason, nous, rede, verstand, Vernunft, akalbudi) manusia; sedangkan manusia adalah suatu "institut" atau "instansi" yang tidak sempurna. Sedangkan kebenaran Agama adalah kebenaran mutlak (absolut) dan sempurna, karena Agama berdasarkan wahyu yang diturunkan oleh Dzat Yang Maha Benar, Maha Mutlak dan Maha Sempurna, yaitu Allah SWT.

${ }^{4}$ Endang Saefuddin Anshari, Wawasan Islam, hlm., 222-223 hlm., 29.

${ }^{5}$ Koko Abdul Kodir. Metodologi Studi Islam. Bandung : Pustaka Setia., 2014., 
tunduk, taat, dan berserah diri kepada Allah SWT. dalam upaya mencari keselamatan dan kebahagiaan hidup di dunia dan akhirat. ${ }^{6}$

Sedangkan pengertian Islam dari segi istilah, banyak ahli yang mendefinisikannya. Harun Nasution mengatakan bahwa Islam menurut istilah (Islam sebagai agama) adalah agama yang ajaran-ajarannya diwahyukan Tuhan kepada masyarakat manusia melalui Nabi Muhammad SAW. sebagai Rasul. Islam pada hakikatnya membawa ajaran-ajaran yang bukan hanya mengenal satu segi, tetapi mengenal berbagai segi dari kehidupan manusia. ${ }^{7}$

Sementara itu, Maulana Muhammad Ali mengatakan bahwa Islam adalah agama perdamaian; dan dua ajaran pokoknya, yaitu keesaan Allah dan kesatuan atau persaudaraan umat manusia menjadi bukti nyata bahwa agama Islam selaras dengan namanya. Islam bukan saja dikatakan sebagai agama seluruh Nabi Allah, sebagaimana tersebut dalam Al-Quran, melainkan pula pada segala sesuatu yang secara tak sadar tunduk sepenuhnya pada undangundang Allah. ${ }^{8}$

Kata Islam jika dicari dalam kamus-kamus bahasa, niscaya akan ditemukan bahwa arti kata Islam itu ialah "tunduk dan patuh kepada perintah orang yang memberi perintah dan kepada larangannya tanpa mem-banlah". Agama kita telah diberi nama Islam, karena ia berarti taat kepada Allah dan tunduk kepada perintah Nya tanpa membantah. ${ }^{9}$

Agama yang dibawa oleh Nabi Muhammad SAW. dan yang dibawa oleh nabi-nabi sebelumnya dinamakan Islam, karena menunjukkan hakikat dan esensi agama tersebut. Arti kata "Islam" adalah masuk dalam perdamaian, dan seorang Muslim adalah orang yang membuat perdamaian dengan Tuhan dan dengan manusia. Damai dengan Tuhan berarti tunduk dan patuh secara menyeluruh kepada kehendak-Nya, sedangkan damai dengan

${ }^{6}$ Rosihon Anwar, dkk. Pengantar Studi Islam. Bandyng. CV. Pustaka Setia. 2014., hlm., 13-14

${ }^{7}$ Harun Nasution, Islam Ditinjau dari Berbagai Aspeknya, UI Press, Jakarta, 1985, hlm. 24.

${ }^{8}$ Rosihon Anwar, dkk. Pengantar Studi Islam, hlm. 14.

${ }^{9}$ Abu A'la Maududi Prinsip-Prinsip Islam. Judul Asli Mabadi Al-Islami. Riyad. National Offfset Printing Press. International Islamic Federation Of Student Organization., 1986.. hlm., 2 
manusia tidak hanya berarti meninggalkan pekerjaan buruk dan menyakitkan orang lain, tetapi juga berbuat baik kepada orang lain. Kedua makna "perdamaian" itu merupakan esensi dari agama Islam. Hal ini dapat dipahami dari firman Allah dalam Al-Quran:

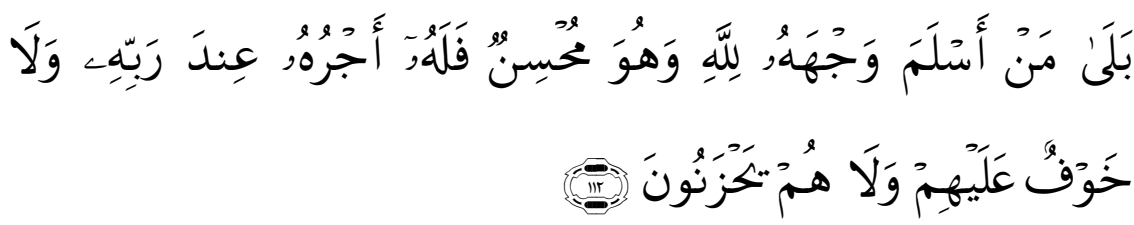

Artinya: (Tidak demikian) bahkan barangsiapa yang menyerahkan diri kepada Allah, sedang ia berbuat kebajikan, Maka baginya pahala pada sisi Tuhannya dan tidak ada kekhawatiran terhadap mereka dan tidak (pula) mereka bersedih hati. ${ }^{10}$

Ayat di atas menunjukkan, Islam pada dasarnya adalah agama perdamaian. dan ajarannya yang pokok adalah keesaan Tuhan. Islam ingin menciptakan kehidupan dunia yang damai dan rukun di antara umat manusia.

Islam adalah agama yang mencakup semua ajaran agama yang sebelumnya telah diturunkan kepada para Nabi dan Rasul Oleh karena itu, Islam menuntut pemeluknya untuk percaya kepada semua agama di dunia yang mendahuluinya yang diturunkan Tuhan. Seorang Muslim juga harus percaya kepada para Nabi dan Rasul yang dibangkitkan sebelum Nabi Muhammad. Al-Quran menyatakan:

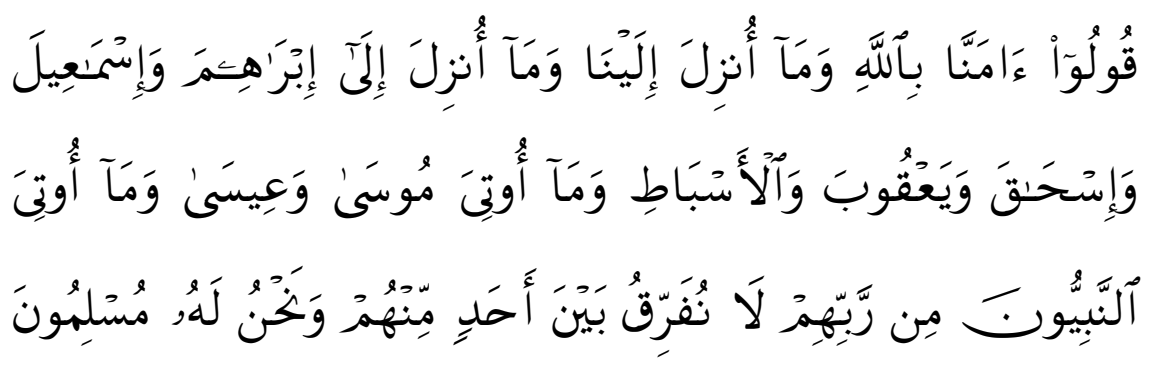

Artinya: Katakanlah (hai orang-orang mukmin): "Kami beriman kepada Allah dan apa yang diturunkan kepada kami,

10 Q.S. Al-Baqarah : 112 
dan apa yang diturunkan kepada Ibrahim, Isma'il, Ishaq, Ya'qub dan anak cucunya, dan apa yang diberikan kepada Musa dan Isa serta apa yang diberikan kepada nabi-nabi dari Tuhannya. kami tidak membeda-bedakan seorangpun diantara mereka dan kami Hanya tunduk patuh kepada-Nya". ${ }^{11}$

\section{Hakekat Islam}

Kehidupan yang terpampang di hadapan manusia Nampak begitu tertata secara rapih dan teratur. Segala sesuatu yang ada di dalam alam ini, tunduk kepada suatu peraturan tertentu dan kepada undang. undang tertentu. Matahari, bulan dan bintang-bintang semua tunduk kepada suatu peraturan yang tetap, tidak dapat bergeser atau menyeleweng dari padanya meskipun seujung rambut.

Di jagat raya yang luas dapat diamati, Bumi berputar mengelilingi sumbunya. la tidak dapat beranjak dari masa, gerak dan jalan yang telah ditetapkan baginya. Air, udara, cahaya dan panas semuanya tunduk kepada suatu sistim yang khas. Bendabenda yang tidak bernyawa, tumbuh-tumbuhan dan binatangbinatang tunduk kepada suatu ketentuan yang pasti, tidak hidup dan tidak mati kecuali menurut ketentuan itu. Hingga manusiapun apabila diperhatikan keadaannya, niscaya ternyata bahwa ia tunduk kepada peraturan-peraturan (sunnah) Allah dengan sepenuhpenuhnya. Ia tidak bernafas dan tidak merasai kebutuhannya akan air, makanan, cahaya dan panas, kecuali menurut undang-undang Allah yang mengatur hidupnya. Juga hati manusia dalam geraknya, darahnya dalam peredarannya dan nafasnya, keluar-masuknya tunduk kepada undang-undang ini jua. Semua anggota badannya. seperti otak, perut besar, paru-paru, urat saraf, urat daging, dua tangan, dua kaki, lidah, dua mata, hidung dan telinga semua berserah-diri kepada-Nya.

Semua fungsi yang ditunaikan oleh anggota-anggota ini, tidak lain dari pada apa yang telah ditakdirkan Allah baginya. Anggota-anggota itu tidak menunaikannya kecuali menurut jalan yang telah ditetapkan baginya.

${ }^{11}$ Q.S. Al-Baqarah : 136 
Undang-undang yang menyeluruh tunduk kepadanya dan tidak terlepas dari pada taat kepadanya suatupun yang ada di dalam alam ini, mulai dari planet yang paling besar di langit sampai kepada butiran pasir yang paling kecil di bumi, adalah ciptaan Raja Yang Maha Besar dan Maha Kuasa. Jika segala sesuatu yang ada di langit dan di bumi serta yang ada di antara keduanya tunduk kepada undan-undang nin, maka alam seluruhnya pasti akan taat kepada Raja Yang Maha Kuasa yang membuatnya dan menurut perintahNya.

Ternyata dari segi ini, Islam adalah Agama alam semesta, karena Islam maknanya ialah berserah diri dan patuh kepada perintah yang memberi perintah dan larangannya tanpa membantah, Jadi, matahari, bulan dan bumi adalah Muslim. Udara, air, cahaya, gelap dan panas adalah Muslim. Pohon kayu, batu dan binatang adalah Muslim. Bahkan manusia yang tidak mengenal Tuhannya, ingkar kepadaNya, menolak ayat-ayatNya, atau menyembah yang lain dari padaNya dan menyekutukan Dia dengan sesuatu, adalah Muslim kercna fitrahnya yang ia diciptakan menurut fltrah itu. Yang demikian itu adalah karena ia tidak dilahirkan, tidak hidup dan tidak mati kecuali menurut undangundang yang dicipta $y$ kan Allah untuk kelahirannya, hidupnya dan matinya. Bcgitu juga seluruh anggota badannya semata-mata tunduk kepada Agama Islam, karena ia tidak tumbuh, tidak menjadi besar dan tidak bergerak kecuali menurut undang-undang Ilah ini sendiri. Bahkan pada hakikat-nya lidahnya yang dipergunakannya untuk melahirkan faham-faham syirik dan kufurnya, karena kebodohannya dan kedangkalan fikirannya, tidak tunduk kecuali kepada Agama Islam. Begitu juga kepalanya yang memaksanya untuk membungkuk di hadapan yang lain dari pada Allah, tidaklah tunduk kecuali kepada agama Islam, dengan kemudi fitrahnya yang ia telah diciptakan meflurut fltrah itu. Begitu juga hatinya yang menyuruhnya untuk menyintai yang lain dari pada Allah dan memujanya karena kebodohannya dan kedangkalan fikirannya, semata-mata adalah Muslim jua, karena 
firhrahnya dan nalurinya. Semua mereka telah berserah diri kepada Allah dan patuh kepada undang-undangNya. ${ }^{12}$

Setiap manusia memiliki pemikiran sendiri-sendiri yang kadang pemikirannyapun berbeda pula. Hal ini karena pada dasarnya manusia di dalam kehidupannya mempunyai dua segi yang berlain-lainan:

Pertama, ia tunduk kepada undang-undang fitrah dan mematuhinya karena nalurinya.

Kedua, ia telah dikaruniai akal, daya untuk memahami, memperhatikan dan menentukan pendapat. Maka ia dapat menerima sesuatu dan menolak yang lain, menyukai sesuatu jalaJi dan membenci yang lain dan menciptakan dari dirinya scndiri sesuatu kaedah untuk berbagai-bagai segi kehidupan atau menerima sesuatu sistim kehidupan yang diciptakan oleh orang Iain. Jadi ia tidak terikat oleh dunia ini, tetapi ia telah diberi kemerdekaan berfikir dan kemerdekaan menentukan pilihannya mengenai pendiriannya dan perbuatannya. ${ }^{13}$

Kedua segi yang berlain-lainan ini terdapat di dalam kehidupan manusia, masing-masing terpisah dari yang lain.

Dari segi yang pertama, ia adalah seorang Muslim yang telah dicetak menurut Islam dan diciptakan untuk momikul tanggung-jawab terhadapnya, sebagaimana makhluk-makhluk yang lain di dalam alam ini. Yang demikian itu tadi telah anda ketahui.

Dan dari segi yang lain ia adalah bebas untuk menentukan pilihannya, apakah ia hendak menjadi seorang Muslim atau bukan Muslim. Kebebasan untuk menentukan pilih inilah yang membagi manusia menjadi dua macam:

Manusia yang mengenal Khaliknya dan percaya kepadaNya sebagai Tuhan, sebagai Pemilik dan sebagai Yang Dipertuan bagi dirinya, dan mengikuti undang-undang Syari'atNya dalam kehidupannya yang bebas pilih, sebagaimana juga ia mengikuti undang-undang alamNya dalam kehidupannya yang tidak bebas pilih. Inilah dia Muslim yang sempurna yang telah menyempurnakan Islamnya, karena hidupnya sekarang lelah

${ }^{12}$ Abu A'la Maududi Prinsip-Prinsip Islam, hlm., 2

${ }^{13}$ Abu A'la Maududi Prinsip-Prinsip Islam. Ibid... hlm., 4 
menjadi Islam yang hakiki. Ia telah berserah diri dengan sukarela kepada yang tadinya ditaatinya dan dipatuhi undang-undangNya tanpa disadarinya sebelumnya. Sekarang dengan sadar dan sengaja ia telah menjadi seorang yang taat kepada Tuhannya, yang sebelum itu ditaatinya dengan tidak di-sengaja dan tidak dikehendakinya. Ilmunya telah menjadi benar, kerana ia telah mengenal Allah, Khaliknya dan Penciptanya yang memberinya kekuatan ilmu dan pelajaran. Akalnya telah masak dan fahamnya telah terarah, karena ia telah mempekerjakan fikirannya kemudian meng-ambil keputusan, bahawa ia Udak mau menyembah selain daripada Alah yang telah mengagkat derajatnya dengan suatu pemberian, berupa laham dan kebebasan menentukan pendirian dalam segala perkara. Lidahnya telah menjadi benar, mengatakan yang hak, karena ia sekarang hanya mengakui Tuhan yang Maha Esa, yaitu Allah yang mengumiainya kekuatan berbicara dan berkata-kata. Seolah-olah hidupnya sekarang tidak ada yang tinggal padanya kecuali kebenaran, karena ia tunduk kepada undang-undang Allah dalam perkara yang ia mempunyai kebebasan memilih mengenai urusannya. Maka terbentanglah antara dia dan makhluk-makhluk yang lain di dalam alam ini tali perkenalan dan pergaulan yang harmonis, karena ia hanya menyembah Allah yang Mahu Bijaksana dan Maha Mengetahui, yang disembah dan dipatuhi undang-undangnya oleh sekalian makhluk. la sekarang adalah khalifaha Allah, yaitu wakilNya di bumiNya. Segala sesuatu yang ada di dunia ini adalah miliknya, sedang ia adalah milik Allah s.w.t. ${ }^{14}$

Berdasarkan uraian di atas dapat dipahami bahwa hakekat Islam adalah keteraturan, kepatuhan, ketundukan makhluk kepada allah pencipta makhluk yang Maha Esa dan maha Kuasa.

\section{Hakekat Sumber Ajaran Islam.}

Sumber ajaran Islam ada dua macam yaitu sumber ajara yang bersifat primer dan sumber ajaran yang bersifat skunder.

\section{a. Sumber Ajaran Islam Primer}

\section{Al-Quran}

${ }^{14}$ Abu A'la Maududi Prinsip-Prinsip Islam. Ibid., 5 
Al-Quran berarti bacaan, merujuk pada sifat Al-Quran yang difirmankan-Nya dalam Q.S. Al-Qiyamah : 17-18, yang artinya:

\section{Hadis}

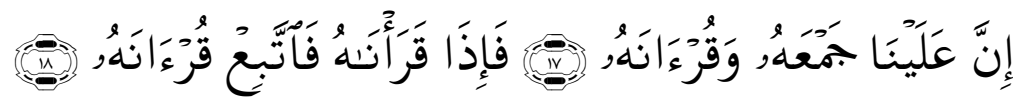

Artinya: "Sesungguhnya Kami yang akan mengumpulkannya (di dadamu) dan membacakannya. Apabila Kami telah selesai membacakannya maka ikutilah bacaannya itu.". ${ }^{15}$

Hadis merupakan sumber ajaran Islam kedua setelah AlQuran. Menurut ulama hadis, pengertian hadis adalah sesuatu yang disandarkan kepada Nabi Muhammad SAW., baik berupa perkataan, perbuatan, taqrir maupun sifat. Adapun menurut ulama ahli ushul fiqh, hadis adalah segala perkataan, perbuatan, dan taqrir Nabi Muhammad SAW. yang berkaitan dengan penetapan hukum. Secara etimologi, hadis adalah jalan atau cara yang merupakan kebiasaan yang baik.

Sunnah adalah segala yang disandarkan pada Nabi Muhammad SAW., baik perkataan, perbuatan maupun taqrir. Kedudukan sunnah sebagai sumber ajaran Islam, selain didasarkan pada keterangan ayat-ayat Al-Quran dan hadis, juga didasarkan pada kesepakatan sahabat

\section{b. Sumber Ajaran Islam Sekunder}

Sumber ajaran Islam sekunder adalah ijtihad. Secara harfiyah, ijtihad adalah pendapat atau pertimbangan. Arti ijtihad adalah melakukan kesungguhan dan ketekunan optimal untuk menetapkan hukum syara'. Jadi, ijtihad dilakukan untuk menetapkan hukum yang tidak dipenuhi dalam Al-Quran dan hadis. Adapun Macam-macam ijtihad adalah meliputi hal-hal sebagai berikut

a) Qiyas

Qiyas berarti mengukur sesuatu dengan yang lain dan menyamakannya. Dengan kata lain, qiyas dapat diartikan sebagai upaya membandingkan suatu perkara dengan perkara lain yang mempunyai pokok masalah atau sebab akibat yang sama.

${ }^{15}$ Q.S. Al-Qiyamah : 17-18 
Contohnya pada surat Al-lsra' ayat 23 dikatakan bahwa perkataan "ah" "cis" atau "hus" kepada orangtua tidak diperbolehkan karena dianggap meremehkan atau menghina, apalagi sampai memukul karena menyakiti hati orangtua.

b) Istihsan

Istihsan, yaitu proses perpindahan dari suatu qiyas pada qiyas lainnya yang lebih kuat. Dengan kata lain, istihsan adalah mengganti argumen dengan fakta yang dapat diterima untuk mencegah kemudharatan atau menetapkan hukum suatu perkara yang menurut logika dapat dibenarkan.

c) Mushalat murshalah

Mushalat mursalah menurut bahasa berarti kesejahteraan umum. Menurut istilah, mushalat mursalah adalah perkara-perkara yang perlu dilakukan demi kemaslahatan manusia.

d) Sududz dzariah

Sududz dzariah menurut bahasa berarti menutup jalan, sedangkan menurut istilah, sududz dzariah adalah tindakan memutuskan suatu yang mubah menjadi makruh atau haram demi kepentingan umat.

e) Istishab

Istishab, yaitu melanjutkan berlakunya hukum yang telah ada dan telah ditetapkan pada masa lalu hingga ada dalil yang mengubah kedudukan hukum tersebut.

f) $U r f$

Urf, yaitu perbuatan yang dilakukan terus-menerus (adat), baik berupa perkataan maupun perbuatan. ${ }^{16}$

\section{Sifat Dasar Ajaran Islam}

Konsep dasar ajaran Islam adalah seluruh alam semesta diciptakan oleh Allah SWT. yang merupakan Tuhan dan Penguasa Alam Semesta, dan Dia pula yang mencukupinya. Diciptakannya manusia, dan masing-masing manusia diberi umur tertentu, Allah SWT. telah menentukan kode kehidupan tertentu yang paling baik bagi manusia, tetapi pada saat yang sama, manusia diberi kebebasan untuk memilih, menerima, atau mengingkari dasar hlm., 50-53

${ }^{16}$ Koko Abdul Kodir. Metodologi Studi Islam. Bandung : Pustaka Setia., 2014., 
kehidupannya sendiri. Ajaran Islam memiliki sifat khas yang berbeda dengan ajaran agama lainnya, yang menjadikannya menarik bagi manusia sepanjang umur dan zaman. ${ }^{17}$

Sifat dasar ajaran Islam menurut pendapat Khursyid Ahmad (1998: 91), sebagaimana dikutip oleh Koko Abdul Kodir, ${ }^{18}$ dalam bukunya yang berjudul Metodologi Studi Islam antara lain sebagai berikut.

\section{Kesederhanaan, Rasionalitas, dan Praktis}

Islam tidak memiliki mitologis. Ajarannya cukup sederhana dan mudah dipahami. Ajaran Islam bersifat rasional, yang dapat dijelaskan oleh logika dan penalaran. Islam mendorong pemeluknya mempergunakan akal serta mendorong penggunaan intelek. Dengan demikian, jelas bahwa Islam merupakan agama yang praktis dan tidak membuat manusia berpuas diri dalam kesiasiaan.

\section{Kesatuan antara Materi dan Rohani}

Islam mendorong manusia untuk mencapai kepuasan dalam kehidupan, tidak memisahkan materiil dan moral, dunia dan ukhrawi, dan mengajak manusia agar mencurahkan tenaga untuk mengonstruksikan kehidupan atas dasar moral yang sehat.

Dengan demikian, Islam menyuruh untuk memadukan antara kehidupan moral dan materi sehingga keduanya saling selaras dan mem-berikan kemanfaatan, bukan dengan kehidupan asketisme (kepertapaan) ataupun dengan ideologi materialistik yang dapat mengabaikan sisi moral dan spiritual kehidupan.

\section{Cara Hidup yang Lengkap}

Islam memberikan tuntunan bagi seluruh aspek kehidupan, baik pribadi dan sosial, moral dan materiil, ekonomi dan politik, legal dan kultural maupun nasional dan internasional.

\section{Keseimbangan antara Pribadi dan Masyarakat}

Islam menciptakan keserasian dan keseimbangan antara individual-isme dan kolektivisme. Keduanya mempunyai hak dan kewajiban sehingga harus ditunaikan secara selaras dan sebaikbaiknya.

17 Khursyid Ahmad, Prinsip-Prinsip Pokok Islam. Jakarta : Rajawali Press. 1998., hlm., 89.

${ }^{18}$ Koko Abdul Kodir. Metodologi Studi Islam, hlm., 53-56 


\section{Universalitas dan Humanisme}

Islam bersifat menyeluruh dan sangat menjunjung tinggi kemanusiaan, menghendaki perdamaian, dan persatuan umat.

\section{Keajegan dan Perubahan}

Keajegan dalam Islam bukan berarti kaku, datar dalam setiap hal. Islam menerima perubahan, tetapi harus dijalankan secara seimbang sehingga prinsip Islam tetap ada tanpa terganggu oleh perubahan yang ada.

\section{Universalisme Islam}

Ajaran islam tidak ditujukan kcpada suatu kelompok atau bangsa tertentu, melainkan sebagai rahmatan li al-'alamin, sesuai dengan misi yang diemban oleh Rasulullah SAW. Ajaran Islam diturunkan Allah SWF untuk dijadikan pcdoman hidup seluruh manusia dalam mencapai kcbahagiaan di dunia dan di akhirat. Dengan demikian. hukum Islam bcrsifat universal, untuk seluruh umat manusia di muka bumi. serta dapat diberlakukan di setiap bangsa dan negara ${ }^{19}$ Firman Allah SWT.:

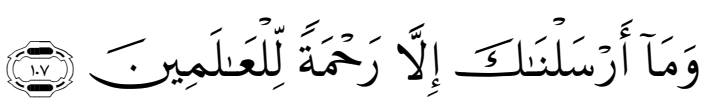

Artinya: Dan tiadalah kami mengutus kamu, melainkan untuk (menjadi) rahmat bagi semesta alam.

Seluruh ajaran Islam baik akidah syariah maupun akhlak bernnua-i rnembe'naskan manusia dari bcrbagai bclenggu penyakit menial-spirituai dan stagnasi berpikir, serta mengatur tingkah laki: pcrbuatan manusia sccara tert'b agar tidak tcrjerumus ke lembah kehinaan dan keterbelakangan. sehingga tercapai kesejahteraan dan kcbahagiaan hidup. baik di dunia maupun di akhirat. Sinkronitas dan integritas dari kctiga aspek tersebut. terlihat dalam universalisme dan universalitas Islam dengan misinya sebagai rahmat bagi seluruh umat manusia. ${ }^{20}$

Atas dasar itulah. muncul diktum Islam sebagai agama yang sempurna. Kesempurnaannya terlihat dalam ajaran-ajarannya yang

${ }^{19}$ Ali Anwar Yusuf. Studi Agama Islam untuk Pergiiruan Tinggi, Pustaka Setia, Bandung. 2003. hlm. 37.

${ }^{20}$ Ali Anwar Yusuf. Wawasaii Islam, hlm. 18. 
bersifat universal dan fleksibel (luas dan luwes) serta mengharuskan terciptanya keseimbangan hidup antara duniawi dan ukhrawi. jasmani dan rohani. Sebab, kehidupan duniawi yang baik harus dijadikan media untuk mencapai kehidupan rohani yang baik. Sebaliknya, kehidupan rohani yang baik harus dijadikan media untuk memenuhi kehidupan jasmani yang baik, legal, dan halal serta di bawah rida Allah. Oleh karena itu, Islam merupakan kekuatan hidup yang dinamis, juga merupakan suatu kode yang sesuai dan berdampingan dengan tabiat alam, dan merupakan kode yang meliputi segala aspek kehidupan insani. ${ }^{21}$

\section{Misi Ajaran Islam}

Studi terhadap misi ajaran Islam secara komprehensif dan mendalam menurut Koko Abdul Karim sangat diperlukan karena beberapa sebab. Pertama, menimbulkan kecintaan manusia terhadap ajaran Islam yang didasarkan pada alasan yang sifatnya bukan hanya normatif, yaitu karena diperintah oleh Allah SWT., dan bukan pula karena emosional semata-mata, tetapi didukung oleh argumentasi yang bersifat rasional, kultural, dan aktual, dengan argumen yang masuk akal, dapat dihayati, dan dirasakan oleh umat manusia. Kedua, membuktikan kepada umat manusia bahwa Islam, baik secara normatif maupun secara kultural dan rasional adalah ajaran yang membawa manusia pada kehidupan yang lebih baik, tanpa harus mengganggu keyakinan agama Islam. Ketiga, menghilangkan citra negatif dari sebagian masyarakat terhadap ajaran Islam. ${ }^{22}$

Argumentasi untuk menyatakan bahwa misi ajaran Islam sebagai pembawa rahmat bagi seluruh alam dikemukakan untuk menunjukkan bahwa Islam sebagai pembawa rahmat dapat dilihat dari pengertian Islam. Makna kata Islam adalah masuk dalam perdamaian, sedangkan orang Muslim adalah orang yang damai dengan Allah SWT. dan damai dengan manusia. Damai dengan Allah SWT., artinya berserah diri sepenuhnya pada kehendak-Nya, sedangkan damai dengan manusia berarti tidak berbuat sewenang-

${ }^{21}$ Ibid.

${ }^{22}$ Koko Abdul Kodir. Metodologi Studi Islam, hlm., 49-50 
wenang kepada sesama, tetapi sebaliknya, berbuat baik kepada sesama.

Dua pengertian di atas, dinyatakan dalam Al-Quran sebagai inti agama Islam yang sebenar-benarnya. Al-Quran menyatakan bahwa "Islam adalah agama perdamaian dan dua ajaran pokoknya, yaitu keesaan Allah dan kesatuan atau persaudaraan umat manusia, menjadi bukti nyata bahwa agama Islam, selaras dengan namanya. Islam bukan hanya merupakan agama sekalian Nabi Allah, sebagaimana dalam penjelasan, melainkan juga sesuatu yang secara tidak sadar tunduk sepenuhnya pada undang-undang Allah, yang kita saksikan pada alam semesta."

Misi ajaran Islam sebagai pembawa rahmat dapat dilihat dari peran Islam dalam menangani berbagai problematika agama, sosial, ekonomi, politik, hukum, pendidikan, kebudayaan, dan sebagainya. Sejak kelahirannya lima belas abad yang lalu, Islam senantiasa hadir memberikan jawaban terhadap permasalahan tersebut. Islam sebagaimana dikatakan H.A.R. Gibb bukan hanya ajaran tentang keyakinan, melainkan juga sebagai sistem kehidupan yang multidimensial.

Sejak kelahirannya, Islam sudah memiliki komitmen dan respons yang tinggi untuk ikut terlibat dalam memecahkan berbagai masalah duniawi. Islam tidak hanya mengurusi sosial ibadah dan seluk-beluk yang berkaitan dengannya, tetapi juga terlibat memberikan jalan keluar yang terbaik untuk mengatasi berbagai masalah tersebut dengan penuh bijaksana, adil, demokratis, manusiawi, dan seterusnya.

\section{Filsafat}

\section{Pengertian Filsafat}

Manusia dalam menjalani hidupnya, secara sadar ataupun tidak sesungguhnya tidak bisa melepaskan diri pada filsafat, karena manusia memiliki akan dan manusia selalu berpikir. Karena itu manusia pada dasarnya adalah makhluk yang berfilsafat (berpikir). Dan inilah sesungguhnya yang membedakan antara manusia dengan makhluk-makhluk lainnya.

Filsafat adalah berpikir dan merasa sedalam-dalamnya terhadap segala sesuatu sampai kepada inti persoalan. Filsafat 
berasal dari bahasa yunani philos dan sophia. Philos artinya "cinta" Sophia adalah ilmu pengetahuan.

Kata filsafat berasal dari bahasa Arab "falsafah atau falsafat". Orang Arab sendiri mengambilnya dari bahasa Yunani "philosophia", yang merupakan kata majemuk dari philos dan sophia. Philos artinya "cinta" dalam arti yang seluas-luasnya, yaitu ingin dan karena ingin itu selalu berusaha mencapai yang diingininya itu. Sedangkan sophia berarti "kebijaksanaan". Bijaksana berarti "pandai", yakni mengerti dengan mendalam. Dengan demikian dari segi bahasa dapat diambil pengertian bahwa filsafat berarti ingin mengerti dengan mendalam, atau cinta kepada kebijaksanaan. ${ }^{23}$

Dalam bahasa Arab dikenal kata "hiikmah dan hakim", kata ini bisa diterjemahkan dengan arti "filsafat dan filosof". Kata "Hukamaul Islam" bisa berarti "falasifatul Islam". Hikmah adalah perkara ter-tinggi yang bisa dicapai oleh manusia dengan melalui alat-alat tertentu, yaitu akal dan metode-metode berfikirnya. ${ }^{24}$ Di dalam Al-Qur ${ }^{\mathrm{A}}$ an surat al-Baqarah ayat 269 dinyatakan :

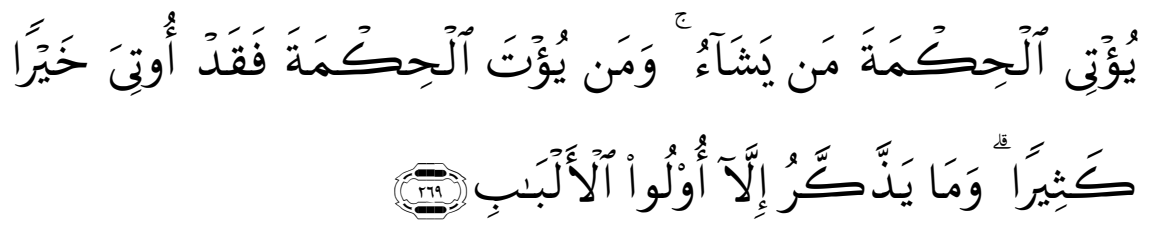

Artinya: Allah menganugerahkan Al hikmah (kefahaman yang dalam tentang Al Quran dan As Sunnah) kepada siapa yang dikehendaki-Nya. dan barangsiapa yang dianugerahi hikmah, ia benar-benar Telah dianugerahi karunia yang banyak. dan Hanya orang-orang yang berakallah yang dapat mengambil pelajaran (dari firman Allah). ${ }^{25}$

Datangnya hikmah itu bukan dari penglihatan saja, tetapi juga dari penglihatan dan hati, atau dengan mata hati dan pikiran yang tertuju kepada alam yang ada di sekitarnya. Karena itu

\footnotetext{
${ }^{23}$ Tadjab, dkk. Dimensi-Dimensi Studi Islam, hlm., 280

${ }^{24}$ Inu Kencana Syafiie. Pengantar Filsafat., Bandung : PT. Refika Aditama., 2010., hlm., 1

${ }^{25}$ QS. Al-Baqarah : 269
} 
kadangkala ada orang yang melihat tetapi tidak memperhatikan (melihat dengan mata hati dan berfikir). Terhadap orang tersebut Allah menyatakan antara lain dalam QS. Al-Hajj ayat 46 :

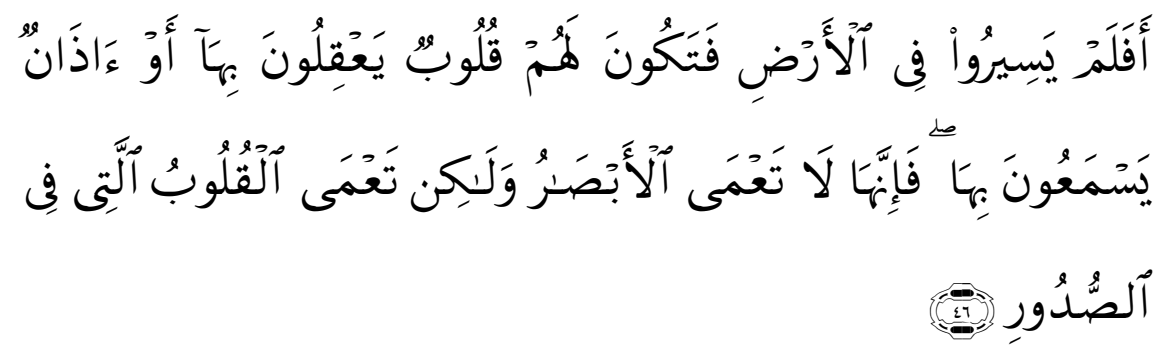

Artinya: Maka apakah mereka tidak berjalan di muka bumi, lalu mereka mempunyai hati yang dengan itu mereka dapat memahami atau mempunyai telinga yang dengan itu mereka dapat mendengar? Karena Sesungguhnya bukanlah mata itu yang buta, tetapi yang buta, ialah hati yang di dalam dada. ${ }^{26}$

Ditinjau dari segi terminologis, filsafat itu mempunyai pengertian yang bermacam-macam tetapi memiliki intisari yang relatif sama. Menurut Harun Nasution ${ }^{60}$ bahwa definisi filsafat itu memang bermacam-macam, antara lain sebagai berikut : (1) pengetahuan tentang hikmah; (2) pengetahuan tentang prinsip atau dasar-dasar; (3) mencari kebenaran; (4) membahas dasar-dasar dari apa yang dibahas, dan lain-lain. Namun demikian dapat dikatakan bahwa intisari filsafat adalah berfikir menurut tata tertib (logika) dengan bebas (tidak terikat pada tradisi, dogma dan sebagainya) dan dengan sedalam-dalamnya sehingga sampai ke dasar-dasar persoalan.

Menurut Endang Saifuddin Anshari" ${ }^{6 "}$ filsafat merupakan "ilmu istimewa" yang mencoba menjawab masalah-masalah yang tidak dapat dijawab oleh ilmu-pengetahuan biasa, karena masalah termak-sud terdapat di luar atau di atas jangkauan ilmu pengelahuan biasa. ${ }^{27}$ Dari beberapa pendapat tersebut dapat difahami bahwa istilah filsafat mengandung pengertian : (1) sebagai aktivitas pikir murni, atau kegiatan akal manusia dalam usaha untuk mengerti secara mendalam segala sesuatu (kesemestaan). Pengertian filsafat di sini ialah berfilsafat; (2)

${ }^{26}$ Q.S. Al-Hajj : 46 :

${ }^{27}$ Endang Saefuddin Anshari, Wawasan Islam, hlm., 122 
sebagai produk kegiatan berfikir murni tersebut. Jadi filsafat merupakan suatu wujud "ilmu" sebagai hasil pemikiran dan penyelidikan berfilsafat itu. Hal itu menunjukkan bahwa filsafat bukanlah hanya sekedar suatu aktivitas berfikir atau suatu proses dan suatu usaha, tetapi mengandung kedua-duanya, baik sebagai aktivitas akal maupun sebagai perbendaharaan sebagai wujud hasil pemiki-ran akal. Dalam arti bahwa filsafat telah berkembang sedemikian rupa sehingga sudah berwujud satu ilmu sendiri.

Sebagai suatu ilmu, filsafat merupakan "ilmu istimewa" yang mencoba menjawab persoalan-persoalan yang belum/tidak dapat dijawab oleh ilmu pengetahuan biasa, karena persoalanpersoalan tersebut ada di luar jangkauan ilmu pengetahuan biasa.

Adapun bagian-bagian atau cabang-cabang dari filsafat itu sendiri meliputi : Pertama, metafisika, yakni filsafat tentang hakekat yang ada di balik fisika, tentang hakekat yang ada yang bersifat transenden, di luar atau di atas kemampuan pengalaman manusia. Bagian pertama ini disebut juga dengan ontologi. Kedua, logika, yakhi filsafat tentang pikiran yang benar dan yang salah. Ketiga, etika, yakni filsafat tentang tingkah laku yang baik dan yang buruk. Keempat, estetika, yakni filsafat tentang karya (kreasi) yang indah dan yang jelek. Kelima, epistemologi, yakni filsafat tentang ilmu pengetahuan. Dan keenam adalah filsafat-filsafat khusus, seperti filsafat alam, filsafat manusia, filsafat agama dan Iain-Iain.

\section{Struktur Filsafat.}

Struktur filsafat dalam persepsi Ahmad Tafsir sebagaimana yang ditulis dalam bukunya yang berjudul Filsafat Ilmu adalah sistematika filsafat. Dalam penjelasannya, bahwa hasil berpikir tentang yang ada dan mungkin ada yang dilakukan oleh manusia telah terkumpul banyak sekali, dalam buku tebal maupun tipis. Setelah disusun secara sistematis, itulah yang disebut sistematika filsafat. Yang inilah yang kemudian dimaksud dengan struktur 
filsafat oleh Ahmad Tafsir sebagaimana ditulis dalam bukunya tersebut. $^{28}$

\section{Cabang-Cabang Filsafat}

Filsafat merupakan ilmu yang paling tua (keberadaannya dimulai sejak manusia mulai berpikir. Selain itu, filsafat pun merupakan merupakan "ilmu istimewa" yang mencoba menjawab masalah-masalah yang tidak dapat dijawab oleh ilmu pengetahuan biasa, karena masalah termaksud terdapat di luar atau di atas jangkauan ilmu pengelahuan biasa. Filsafat sebagai ilmu memiliki cabang-cabang. Adapun rabang-eabangnya adalah sobagai berikut:

a. Metafisika, filsafat ten tang hakikat yang ada di balik fisika, tentang hakikat yang ada yang bersifat transenden, di luar atau di atas kemampuan pengalaman manusia;

b. Logika, filsafat tentang fikiran yang bonar dan yang salah;

c. Etika, filsafat tentang tingkah-laku yang baik dan buruk;

d. Estetika, filsafat tentang karya (kre'asi) yang indah dan yang jelek;

e. Epistemologi, filsafat tentang ilmu pengetahuan;

f. Filsafat-filsafat khusus lainnya (seperti: Filsafat Hukum, Filsafat Sejarah, Filsafat Alam Filsafat Agama dan lain sebagainya). ${ }^{29}$

Terkait dengan cabang-cabang filsafat, Ahmad tafsir menjelaskan bahwa filsafat terdiri atas tiga cabang besar yaitu: ontologi, epistemologi, dan aksiologi. Ketiga cabang itu sebenarnya merupakan satu kesatuan:

a. ontologi, membicarakan hakikat (segala sesuatu); ini berupa pengetahuan tentang hakikat segala sesuatu;

b. epistemologi cara memperoleh pengetahuan itu;

c. aksiologi membicarakan guna pengetahuan itu.

Ontologi mencakupi banyak sekali filsafat, mungkin semua filsafat masuk di sini, misalnya Logika, Metafisika, Kosmologi, Teologi, Antropologi, Etika, Estetika, Filsafat Pendidikan, Filsafat Hukum dan Iain-lain. Epistemologi hanya mencakup satu bidang saja yang disebut Epistemologi yang membicarakan cara

${ }^{28}$ Ahmad Tafsir,Filsafat Ilmu Mengurai Ontologi. Epistemologi dan Aksiologi. Bandung. PT. Remaja Rosda Karya. 2015., hlm., 68

${ }^{29}$ Endang Saefuddin Anshari, Wawasan Islam, hlm., 222. 
memperoleh pengetahuan filsafat. Ini berlaku bagi setiap cabang filsafat. Sedangkan aksiologi hanya mencakup satu cabang filsafat yaitu Aksiologi yang membicarakan guna pengetahuan filsafat. Ini pun berlaku bagi semua cabang filsafat. Inilah kerangka struktur filsafat. $^{30}$

\section{ISLAM DAN FILSAFAT}

\section{Ajaran Islam Mendorong Berfilsafat.}

Filsafat merupakan aktivitas akal manusia dalam usaha memahami secara mendalam dan radikal terhadap segala sesuatu (kesemestaan).

Agama Islam memberi penghargaan yang tinggi terhadap akal, tidak sedikit ayat-ayat Al-Qur ${ }^{\mathrm{A}}$ an yang menganjurkan dan mendorong manusia supaya banyak berfikir dan menggunakan akalnya. Di dalam Al-Quran dijumpai perkataan yang berakar dari kata "aql (akal) sebanyak 49 kali, yang semuanya dalam bentuk kata kerja" aktif, seperti "aqaluh; ta'qilun; na^qil; ya'qiluha; dan ya"qilun.

Kata-kata yang dipakai dalam Al-Quran untuk menggambarkan perbuatan berfikir bukan hanya "aqala, tetapi juga kata-kata : nazhara (melihat secara abstrak, dalam arti berfikir dan merenungkan), misalnya Q.S. Al-Thariq ayat 5-7 dan sebagainya; tadabbara (merenungkan), misalnya Q.S. Shad ayat 29 dan Iain-Iain; tafakkara (berfikir) seperti Q.S. al-Nahl ayat 6869 dan Iain-Iain; faqiha (mengerti, faham), seperti Q.S. al-lsra' ayat 44; tadzakkara (mengingat, rnemperoleh peringatan, mendapat pelajaran, mem-perhatikan dan mempelajari), seperti Q.S. al-Nahl ayat 17', al-Zumar ayat 9 dan Iain-Iain; fahima (memahami) seperti dalam Q.S. al-Anbiya" 78-79. dan Iain-Iain.

Selain itu di dalam Al-Quran juga terdapat sebutan-sebutan yang memberi sifat berfikir bagi seorang muslim, yaitu ulu al-bab (orang berfikiran), seperti dalam Q.S. Yusuf ayat 111; ulu al-'ilm (orang berilmu), seperti dalam Q.S. Ali Imran ayat 18; ulu alabshar (orang yang mempunyai pandangan), seperti dalam Q.S. al-

${ }^{30}$ Ahmad Tafsir,Filsafat Ilmu Mengurai Ontologi. Epistemologi dan Aksiologi. Bandung. PT. Remaja Rosda Karya. 2015., hlm., 67 
Nur ayat 44; ulu al-nuba (orang bijaksana), seperti dalam Q.S. Thaha ayat 128.

Semua bentuk ayat-ayat tersebut mengandung anjuran, dorongan bahkan perintah agar manusia banyak berfikir dan menggunakan akalnya. Hal ini menunjukkan bahwa agama Islam menganjurkan, mendorong dan bahkan memerintahkan kepada pemeluknya supaya berfilsafat.

Di samping itu anjuran dan dorongan untuk berfilsafat dapat difahami dari pengertian kata ayat itu sendiri. Kata ayat sendiri erat kaitannya dengan perbuatan berfikir. Arti asal dari kata ayat adalah tanda. Sebagaimana diketahui bahwa tanda itu menunjukkan kepada sesuatu yang terletak di belakang tanda itu. Tanda itu harus diperhatikan, difikirkan, diteliti dan direnungkan, baik secara filosofis maupun ilmiah, untuk mengetahui arti yang terletak di belakangnya.

Di dalam AI-Quran, ayat dalam arti tanda itu juga dipakai terhadap fenomena alam yang banyak disebut dalam ayat kauniyah atau ayat tentang kosmos. Sebagai contoh, dalam Q.S. al-Baqarah ayat 164 :

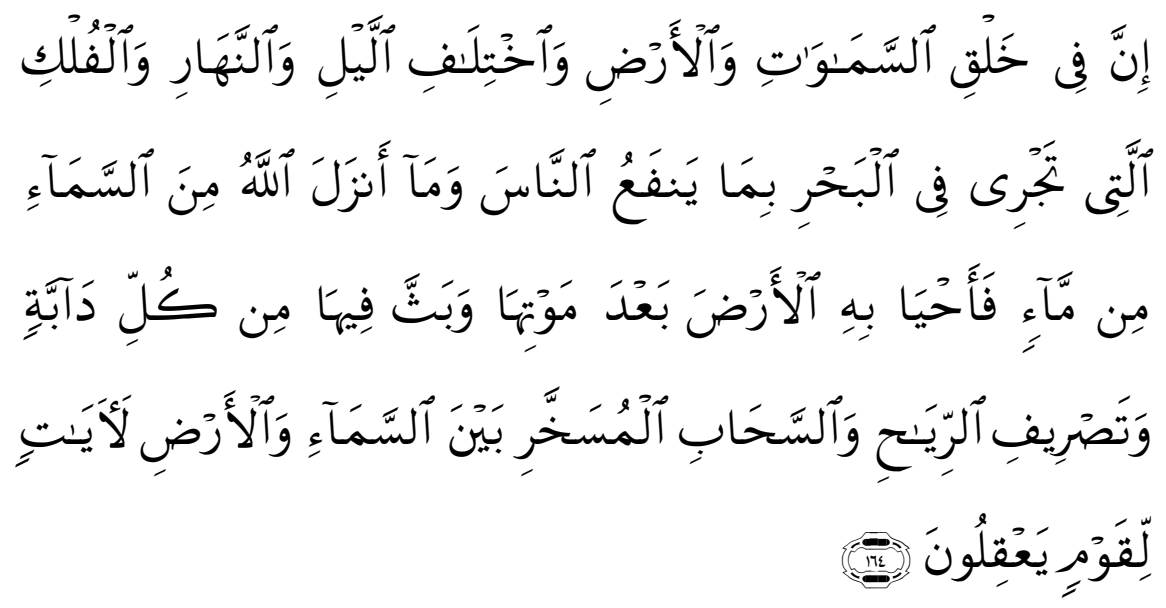

Artinya: 'Sesungguhnya dalam penciptaan langit dan bumi, perubahan ma/am menjadi siang, kapal-kapal yang berlayar di laut membawa apa yang berman/aat bag/ manus/a, air yang diturunkan Allah dari langit kemudian la hidupkan dengannya bumi seteiah ia gersang dan la tebarkan padanya sega/a macam binatang, perkisaran 
ang/'n dan awan yang terletak tunduk di antara langit dan bumi, pada semua ini terdapat tanda-tanda bagi kaum yang mempergunakan akal".

Dari firman Allah tersebut dapat difahami bahwa di dalam kosmos ini penuh dengan tanda-tanda yang harus diperhatikan, diteliti dan difikirkan serta direnungkan oleh manusia, baik secara ilmiah maupun filosofis, untuk mengetahui rahasia yang terletak di be-lakang tanda-tanda itu. Pemikiran secara mendalam terhadap tanda-tanda tersebut akan membawa kepada pemahaman tentang fenomena-fenomena alam sendiri dan akhirnya membawa kepada keyakinan yang mantap terhadap adanya Tuhan Pencipta alam semesta dan hukum alam (sunnatullah) yang mengatur perjalanan alam.

\section{Masuknya Filsafat Yunani Kedalam Islam}

Ketika membicarakan tentang Islam dan filsafat maka tidak bisa dilepaskan keberadaan filsafat Yunani. Hal ini mengingat dimulai dari pemikiran Yunani inilah munculnya kesadaran manusia secara akliah yang mampu berfikir secara radikal untuk memecahkan rahasia alam atau yang maujud ini dan melihat hakekat ketuhanan dengan pendekatan akal. Sungguhpun hasilnya belum sempurna, tetapi usaha itu merupakan awal kemampuan manusia berfikir secara rasional yang pada gilirannya melahir-kan peradaban baru dalam sejarah kehidupan manusia. ${ }^{32}$

Sekitar abad VI SM, di Yunani kuno telah lahir beberapa tokoh pemikir yang masyhur, seperti Thales (640 SM), filosof pertama yang lahir di Miletus ${ }^{69}$. Kemudian disusul dengan Anaximander, Anaxi-menes, dan Heraclitos yang hidup sekitar tahun 500 SM.

Perkembangan pemikiran Yunani telah mencapai puncaknya pada sekitar tahun 500 - 300 SM, yakni sejak muncuInya Socrates yang lahir di Athena pada tahun 470 SM, dan meninggal pada usia 71 tahun, pada tahun $399 \mathrm{SM}^{7}$ " Diteruskan oleh Plato, yang hidup pada tahun 427-347 SM, salah seorang murid dari Socrates, sekaligus sebagai guru dari Aristoteles Aristoteles lahir di Stagira Mace-don tahun 384 SM, meninggal tahun 322 SM, pada usia 17 tahun ia pergi belajar ke Athena menjadi murid dari Plato di Akademi Athena, ketika ia berusia 40 tahun, Plato meninggal

${ }^{31}$ Q.S. al-Baqarah : 164 hlm., 287-288

32 Tadjab, dkk. Dimensi-Dimensi Studi Islam. Surabaya : Karya Aditama. 1994., 
dunia, dan ia men-dirikan lembaga pendidikan yang baru di Lycium. ${ }^{33}$

Pada akhir hidup Aristoteles, Alexander Yang Agung mengalahkan Dairus pada tahun 331 SM, tetapi Alexander tidak menghancurkan kebudayaan Persi, (melainkan menyatukan kebudayaan Persia dan Yunani.

Setelah wafatnya Alexander Yang Agung, kerajaan yang besar itu terbagi menjadi 3 (tiga), yaitu : (1) Macedonia di Eropa; (2) Kerajaan Ptolemeus di Mesir dengan Alexandria sebagai ibukota; dan (3) Kerajaan Seleucid (Seleucus) di Asia dengan kotakota penting Antioch di Syria, Seleucia. di Mesopotamia dan Bactra di Persi sebelah Timur.

Dari ketiga pusat kerajaan itulah yang nantinya menjadi jembatan yang mewariskan pemikiran Yunani ke dunia Islam. Namun Macedonia sendiri nampaknya tidak menjadi jembatan langsung, tetapi ada satu kota di dekat Bagdad, yakni Yundi Shapur.

Ada tiga kota penting yang menjadi jembatan masuknya filsafat Yunani ke dunia Islam, yakni; 1) Iskandariyah : 2) Syria dan 3) Yundi Shapur. . Tiga kota penting tersebut merupakan kotakota" kunci untuk memasuki pemikiran filsafat Yunani bagi dunia Islam. Setelah lahirnya Islam di Mekah mampu memperluas wilayah kekuasaannya, menaklukkan Mesir, Syria, Bagdad, Persia, maka boleh dikatakan bahwa seluruh wilayah pusat ilmu pengetahuan dunia telah berpindah ke tangan kekuasaan Islam. Namun demikian ternyata masuknya filsafat Yunani tidak secepat yang diduga, dari mulai di-kuasainya wilayah tersebut sekitar abad VII, baru pada abad IX dan X, filsafat Yunani mulai berpengaruh secara nyata. Hal ini mungkin disebabkan oleh dua hal, pertama : umat Islam masih sibuk mengembangkan ilmu pengetahuan Islam, seperti hadits, fiqih, ilmu kalam dan sebagainya. Kedua : umat Islam terlalu hati-hati untuk mengambil ilmu-ilmu di luar Islam, sebab di-khawatirkan mengganggu keimanan umat, dan atau memang membenci sesuatu yang di luar Islam.

Masuknya filsafat Yunani ke dalam dunia islam terjadi melalui beberapa hal, diantaranya:

1. Pertama. Melalui kontak secara tak sengaja

Sebenarnya masuknya filsafat Yunani ke dalam dunia Islam terjadi secara tidak sengaja, dalam arti bahwa umat Islam

${ }^{33}$ Tadjab, dkk. Dimensi-Dimensi Studi Islam. Ibid.,

${ }^{34}$ Tadjab, dkk. Dimensi-Dimensi Studi Islam. Ibid., 
tidak sengaja mencari filsafat Yunani untuk dipelajari. Masuknya filsafat Yunani ke dunia Islam terjadi secara alami, sebagai hasil interaksi antar masyarakat Islam dengan bangsa Syria, Persia, dengan wilayah lain yang secara tidak langsung telah membahas ilmu kedokteran, kimia ke dalam Islam.

Yang pertama kali, dipelajari oleh umat Islam adalah ilmu kedokteran. Hal ini terjadi pada masa khalifah Marwan bin Hakam $(64-65 \mathrm{H})$ ketika dokter Maserqueh menerjemahkan kitab Pastur Ahran bin Ayun, yang berbahasa Suryani ke dalam bahasa Arab. Kitab ini disimpan di perpustakaan sampai masa pemerintahan Umar bin Abdul Aziz (99 - 101 H). Umar bin Abdul Aziz beristikharah dahulu untuk mengeluarkan kitab ini agar dimanfaatkan dan diambil faedahnya bagi umat Islam. Dalam riwayat lain ada yang menga-takan bahwa penerjemahan yang pertama kali dalam Islam dilakur kan oleh Khalid bin Yazid al-Amawi $(85 \mathrm{H})$ yang memerintahkan menerjeunihkan kitab-kitab Kimia ke dalam bahasa Arab.

2. Kedua. Masuknya filsafat Yunani melalui kegiatan terjemah :

Kalau dalam uraian di atas telah dikemukakan bahwa motif masuknya filsafat Yunani ke dalam dunia Islam terjadi secara tidak langsung, maka pada pemerintahan Bani Abbas, setelah pusat pemerintahan dipindahkan dari Damaskus (Syria) ke Bagdad (Irak), kegiatan penerjemahan dilakukan secara besar-besaran dan ditangani secara serius.

Al-Makmun memprakarsai penerjemahan tersebut dengan dua alasan utama, yaitu : pertama, banyaknya perdebatan mengenai soal-soal agama antara kaum muslimin di satu pihak dengan orang-orang Yahudi dan Nasrani di pihak lain. Untuk mengh-adapi perdebatan tersebut, mereka memerlukan filsafat Yunani agar dalil-dalil dan pengaturan alasan bisa disusun dengan sebaik-baiknya, sehingga bisa mengimbangi lawanlawannya yang terkenal memakai ilmu Yunani terutama Iogika. Kedua, banyaknya kepercayaan dan pikiran-pikiran Iran yang masuk kepada kaum muslimin, orang-orang Iran dalam menguatkan kepercayaan memakai ilmu berfikir yang didasarkan atas filsafat Yunani.

Di zaman Bani Umaiyah, karena perhatian banyak tertuju pada kebudayaan Arab, maka pengaruh kebudayaan Yunani terhadap Islam belum begitu kelihatan. Pengaruh itu baru nyata atau kelihatan pada masa Bani Abbas, karena yang berpengaruh di pusat pemerintahan bukan lagi orang-orang Arab, tetapi 
orang-orang Persia, seperti keluarga Baramikah, yang telah lama berkecimpung dalam kebudayaan Yunani. ${ }^{85}$

Secara umum, penerjemahan filsafat .Yunani ke dalam Islam terbagi dalam dua tahapan utama, yaitu :

Tahap pertama, penerjemahan secara tidak langsung, dalam arti filsafat Yunani diterjemahkan dalam bahasa Arab melalui tangan kedua, yaitu di bawah pengaruh Ploti-nus, Sutiah, dan dari tangan-tangan para filosof di Yundi Shapur. Dalam terjemahan ini juga dilakukan oleh orang-orang ahli bahasa Suryani, Syria dan Persi yang kebanyakan para penerjemahnya ter-diri dari orang-orang Nasrani.

Tahap kedua, setelah para ahli atau pemikir Islam mengenal filsafat Yunani lewat penerjemahan tersebut, mereka baru mengadakan rekonstruksi pemikiran filosuf Yunani, selanjutnya mengadakan pensyarahan yang pada giliran selanjutnya mampu melahirkan filsafat yang murni dalam arti merupakan pemikiran para filosof muslim sendiri, seperti : alKindi, Al-Farabi, Ibnu Sina, Ibnu Rusyd dan sebagainya...

Puncak penerjemahan tersebut terjadi pada masa khalifah Al-Makmun yang pada tahun $215 \mathrm{H}$ mendirikan Bait alHikmah, di mana para penerjemahnya dan pimpinannya ditangani oleh orang-orang yang menguasai bahasa Suryani, Yunani dan Bahasa Arab de-ngan baik, dan pimpinan Bait alHikmah ini dipegang oleh Hunain Ibn Ishaq'. ${ }^{36}$

Masuknya filsafat tersebut juga telah melahirkan filosoffilosof muslim yang terkenal dalam dunia Barat dan Timur, antara lain : Al-Kindi, Al-Farabi, Ibnu Sina, Al-Ghazali, Ibnu Rusyd, Ibnu Bajah, Ibnu Thufail, Ikhwanusshafa, Ibnu Miskawaih dan lain-lainnya. Namun hal itu bukan berarti bahwa semua pemikir Islam menerima pemikiran Yunani tersebut. AlGhazali misalnya, telah menolak hasil-hasil pemikiran filosof muslim yang didasarkan atas pemikiran Yunani, yang nyatanyata bertentangan dengan ajaran Islam, dalam bukunya Tahafut al-Falasifah. Selanjutnya Ibnu Rusyd membela filosof muslim dan menolak kesimpulan al-Ghazali dalam bukunya Tahafut aLTahafut. hlm., 292

${ }^{35}$ Tadjab, dkk. Dimensi-Dimensi Studi Islam. Surabaya : Karya Aditama. 1994.,

${ }^{36}$ Tadjab, dkk. Dimensi-Dimensi Studi Islam.Ibid., 


\section{E. PENUTUP}

Islam sebagai agama yang menghargai kedudukan akal tentu saja sangat apresiasi terhadap kehadiran fulsafat karena pada dasarnya antara filsafat yang menggunakan akal sebagai cara memperoleh kebenaran memiliki titik temu dengan Islam yang sangat menghargai penggunaan akal.

Masuknya Filsafat yunani ke dalam dunia Islam adalah melalui tiga kota penting yang menjadi jembatan masuknya filsafat Yunani ke dunia Islam, yakni; 1) Iskandariyah : 2) Syria dan 3) Yundi Shapur.

Adapun proses masuknya filsafat Yunani kedalam dunia islam diantaranya dengan cara kontak secara tidak sengaja dan penerjemahan buku-buku filsafat Yunani. Ke dalam bahasa Arab, yang kemudian dibaca dan mempengaruhi pemikiran orang-orang Islam sehingga lahirlah tokoh-tokoh filosof muslim seperti Al- Farabi, al-Kindi AlGhazali dan lain sebagainya.

\section{DAFTAR BACAAN}

Abu A'la Maududi Prinsip-Prinsip Islam. Judul Asli Mabadi Al-Islami. Riyad. National Offfset Printing Press. International Islamic Federation Of Student Organization., 1986.

Ahmad Khursyid, Prinsip-Prinsip Pokok Islam. Jakarta : Rajawali Press. 1998

Ahmad Tafsir,Filsafat Ilmu Mengurai Ontologi. Epistemologi dan Aksiologi. Bandung. PT. Remaja Rosda Karya. 2015

Ali Anwar Yusuf. Studi Agama Islam untuk Pergiiruan Tinggi, Pustaka Setia, Bandung. 2003.

Ansal Bahtiar, Filsafat Ilmu. Jakarta: PT Raja Grapindo Persada., 2004.

Ayi Sofyan. Kapita Selekta Filsafat., Kairo : Maktabat al-Nahdat alMisriyyah, 1964, Juz VIII

Endang Saefuddin Anshari, Wawasan Islam. Jakarta : Rajawali Press. 1982

Harun Nasution. Filsafat Agama. Bandung : Bulan Bintang. 1973

Inu Kencana Syafiie. Pengantar Filsafat., Bandung : PT. Refika Aditama., 2010

Koko Abdul Kodir. Metodologi Studi Islam. Bandung : Pustaka Setia., 2014

Muhaimin dkk., Dimensi-Dimensi Studi Islam Surabaya L Karya Aditama. 1994

---------., Kawasan dan Wawasan Studi Islam Jakarta : Prenada Media. 2005

Stefanus Supriyanto, Dfilsafat Ilmu, Jakarta : Prestasi Pustaka Publisher. 2013 
Rosihon Anwar, dkk. Pengantar Studi Islam. Bandyng. CV. Pustaka Setia. 2014

Tadjab, dkk. Dimensi-Dimensi Studi Islam. Surabaya : Karya Aditama. 1994. 